\title{
EENE BELANGRIJKE VRETERIJ VAN DE BEUKEN- BORSTELRUPS OF DEN ROODSTAART (Dasychira pudibunda L.) IN HET ELSPETER BOSCH.
}

Op 5 October j.l. ontving ik van den Directeur-Generaal van den Landbouw de mededeeling, dat Z. K. H. Prins Hendrik der Nederlanden zijnen wensch had te kennen gegeven, dat ik hem zou vergezellen bij een bezoek aan het Elspeter bosch, waar eene ernstige rupsenplaag heerschte. Op 6 October begaf ik mij naar het Loo, en van daar uit werd het geteisterde bosch bezocht door Z. K. H. den Prins, den Heer G. E. Tutein Nolthenius, Opperhoutvester van H. M. de Koningin, den Heer V. R. Y. Croesfen, Secretaris der Koninklijke Nederlandsche Landbouwvereeniging, den Heer Jhr. H. M. F. Sandberg van LEUVENUM, Voorzitter van de Vennootschap „Elspeter Veegde” en den ondergeteekende.

Het bleek, dat de rups, die hier schadelijk optrad, was de zoogenoemde "roodstaart" of "beukenborstelrups", Dasychira (=:-Orgyia) pudibunda $L$. De plaag heerschte over eene oppervlakte beukenbosch van ongeveer 50 H.A. Op vele plaatsen waren de beuken geheel en al kaalgevreten, zoodat er zelfs geen blaadje meer aan de boomen te bekennen was; op andere plaatsen zag men nog wel eenig blad of stukken blad aan de beuken, maar toch maar weinig. Enkele eiken, die tusschen de beuken verspreid waren, stonden althans niet geheel kaal; men vond er nog gave bladeren of althans stukken van bladeren aan. Zelfs de boschbesstruiken, waarmee de bodem op vele plaatsen bedekt was, waren grootendeels afgevreten door de tallooze rupsen, die de beuken hadden verlaten en den bodem hadden opgezocht, omdat zij op de boomen geen voedsel meer vonden. De knoppen der beuken waren ongeschonden, maar van sommige van deze boomen waren verscheiden kaalge- 
vreten éénjarige twijgjes afgestorven. Het wemelde van rupsen, zoowel in de kronen der beuken als tegen de stammen en en ook op den grond, en op de boschbesstruiken, die den bodem bedekten.

Ik wil hier, naar aanleiding van de plaag in het Elspeter bosch, eerst de kenmerken en vervolgens de levensgeschiedenis van het insekt, dat hier de schade aanrichtte, behandelen, daarna de aandacht wijden aan de bestrijdingsmiddelen, die zouden kunnen worden aangewend, om eindelijk aan te geven wat in het Elspeter bosch tegen het insekt is gedaan, en wat er nog te doen zou zijn.

De beukenborstelrups ontstaat uit de eieren van eenen tot de Spinners (Bombyciden) behoorenden vlinder, de beukenspinner (Dasychira pudibunda) genoemd.

De grootte van den vlinder varieert nog al sterk: de lichaamslengte bedraagt minstens 15 , hoogstens $25 \mathrm{mM}$.: de vlucht varieert tusschen 35 en $65 \mathrm{mM}$ : : bij de onder normale omstandigheden uitgegroeide exemplaren varieert de vlucht meestal tusschen 45 en $60 \mathrm{mM}$; waarbij dient te worden in aanmerking genomen, dat de mannetjes in 't algemeen kleiner zijn dan de wijfjes. Het borststuk en de voorvleugels zijn wit grijs, eenigszins geel- of roodachtig getint. De voorvleugels zijn donker gewolkt, met twee duidelijke evenwijdige bruingrijze dwarsstrepen. Het achterlijf en de achtervleugels zijn lichter van kleur dan het borststuk en de voorvleugels; de achtervleugels zonder de donkerder bruine teekeningen, maar wel met eene onregelmatige, grijze dwarsstreep. De sprieten zijn wit, bij het mannetje met groote, bruingele, bij het wijfje met veel kleinere, evenzoo gekleurde kamvormige aanhangselen. De pooten zijn grijswit. ')

1) Eene uitvoeriger beschrijving vindt men in P. C. T. SNELLEN, „De Vlinders van Nederland; Macrolepidoptera (1867)", bl. 172. 
De vlinder vliegt in 't laatst van Mei en het begin van Juni. Het wijfje legt dan hare eieren, meestal aan de stammen, in hoopen van zeer verschillend aantal, varieerend tusschen 50 en 400 stuks; die eieren zitten in eene enkele laag naast elkander. De eieren zelve zijn plat, witachtig grijs van kleur. De eihoopjes in hun geheel hebben eene eenigszins licht blauwachtig grijze tint; zij zijn glad, niet, zooals de eihoopen van vele verwanten (donsvlinder, plakker, enz.), met haren bedekt, die het leggende wijfje uit haar achterlijf trekt.

De rupsen ziet men van af Juli tot in 't midden of de tweede helft van October. De volwassen rups bereikt eene lengte van 35-40 $\mathrm{mM}$. Zij heeft een grooten, licht geelbruinen kop. De grondkleur van de rest van het lichaam is groenachtig geel, zwavelgeel, rose of roodachtig bruin; in overlangsche rijen geplaatste kleine wratjes dragen matig lange haren van dezelfde kleur als de grondkleur van 't lichaam. Op de rugzijde van het $4 \mathrm{e}$ tot $7 \mathrm{e}$ lichaamslid vindt men bundels van zijdeachtige haren, welke allen precies even lang zijn, zoodat zoo'n haarbundel zich voordoet, alsof hij van boven met een schaar was afgeknipt. Tusschen iederen haarbundel en den volgenden ziet men een fluweelzwarten dwarsband. Aan het achtereinde van het lichaam, op het $11 \mathrm{e}$ lid, staat een vrij lange, roode of roodbruine haarkwast. (Van daar de naam „roodstaart"). Wanneer de rups wordt verontrust, rolt zij zich ineen.

Alle jonge, pas uit het ei gekomen rupsen hebben eene groenachtige grondtint, die echter door lange, zwarte haren bijkans geheel aan het oog wordt onttrokken. De haarbundels en de staartborstel (de haarkwast aan het achtereinde des lichaams) ontbreken nog. Deze vertoonen zich eerst na de eerste vervelling.

De uitwerpselen der rupsen, waarmee ten tijde van eene ernstige vreterij de bodem als bedekt is, bestaan uit dikke, donkergrauwe, cylindervormige brokjes, waarover zich in de 
lengte zes overlangsche groeven uitstrekken: een gevolg van de aanwezigheid van zes overlangsche slijmvliesplooien aan de binnenvlakte van den endeldarm.

De pop heeft hoogstens $3 / 4$ van de lengte der volwassen rups; zij is donkerbruin van kleur en bedekt met geclachtige haren. Men vindt haar van af het laatst van October, omgeven door eene uit twee lagen bestaande, grauwachtige cocon: de binnenste laag is vrij dicht, ofschoon toch doorzichtig; de buitenste laag bestaat uit een zeer los weefsel, waarin rupseharen vastzitten. Men vindt de cocon vastgehecht aan op den grond liggende bladeren of aan hei- en boschbesstruiken.

De beukenspinner wordt gevonden in het grootste gedeelte van Europa; men treft hem aan van Zweden en Petrograd (Petersburg) tot in Midden-Italië, en van af Engeland '), tot in Aziatisch Rusland. Echter komt hij in 't algemeen meer voor in het midden van Europa dan in het Noorden en het Zuiden van dit werelddeel. In de meeste streken komt hij niet dan in betrekkelijk gering aantal voor; tot eene zóó sterke vermeerdering, dat hij geheele beukenbosschen kaal vreet, komt het slechts in sommige jaren en slechts in bepaalde gedeelten van Europa. AlTum ${ }^{2}$ ) deelt mee, dat men zoodanige vermeerdering alleen in het Oosten van dit werelddeel kent, en wel slechts in die streken, welke ten Oosten van de Elbe gelegen zijn; maar dit geldt - volgens hem - alleen van de

1) In Engeland heeft echter de vreterij van Das; chira pudibunda in in beukenbosschen geene groote beteekenis; want in A. T. GilLLANDERS, „Forest entomology" (2e druk, 1912) wordt het insekt niet eens genoemd. Wel komt de rups van deze soort daar zeer veel voor als schadelijk insekt op de hop (van daar de naan "Hop dog" (zic Miss E. A. ORMEROD "Manual of injurions insects", 1881, bl. 107); en in THEOBALD "s „Report on economic zoology" over het jaar, loopende tot ultimo September 1913" wordt melding gemaakt van eene belangrijke beschadiging door dit nsekt aan appelboomen.

$\left.{ }^{2}\right)$ Altum, „Forstzöologie”, III (1874), 2te Abteilung, bl. 93. 
meer Noordelijke streken van Midden-Europa; want bijv. in de Vogezen vermeerdert zich de beukenspinner soms in die mate, dat geheele bosschen kaal gevreten worden. Later echter heeft zich blijkbaar het gebied, waar massale vermeerdering van dit insekt plaatsgrijpt, meer naar het Westen uitgebreid; want Judeich en Nitsche ') vermelden dat zoodanige vermeerdering werd geconstateerd - behalve op Rügen, aan de Oostzeekust en in Brandenburg - cok o. a. in de Vogezen, het Haardt gebergte, het Westerwald, den Taunus, den Harz. Het schijnt dat elders in Europa nooit massale vermeerdering van den roodstaart werd opgemerkt; in Nederland althans nooit vóór dit najaar (1914.) Het eiland Rügen is bijzonder bekend om zijne pudibunda-plagen.

Thans moge hier van de leefwijze van den beukenspinner een overzicht volgen. Zooals reeds werd meegedeeld, zijn de voiwassen vlinders in de tweede helft van Mei en 't bagin van Juni te vinden. Zij zijn zeer traag, en zitten met vooruitgestrekte voorpooten en samengeslagen vleugels over dag tegen de stammen der boomen aan, ook wel aan heide, boschbes en andere struiken, die den bodem bedekken. Bij nacht gaan zij vliegen, vooral de mannetjes, die dan de wijfjes opzoeken. Toch vliegen ook de wijfjes vrij veel bij nacht. De eieren worden in hoopen tegen de boomstammen vastgehecht. (Beschrijving: zie boven, bl. 117). E. L. TASCHENBERG ${ }^{2}$ ) schrijft dat de eieren afzonderlijk, niet in hoopen, gelegd worden. Deze onjuiste meening laat zich waarschijnlijk verklaren uit het feit, dat de eieren van een hoop slechts los aaneenkleven en derhalve gemakkelijk loslaten; zoo kunnen er verscheiden uit zoo'n eiklomp op den grond vallen en blijven de overigen dan afzonder-

1) JUDEICH und NiTSCHE, "Lehrbuch der mitteleuropäischen Forstinsektenkunde", II, blz. 789 (1895).

") E. L. TASCHENBERG, „Forstwirtschaftliche Insektenkunde” (1874), bl. 345 . 
lijk, niet in hoopen, aan den stam zitten. - Men vindt de eihoopen voor 't meerendeel op ongeveer twee maal manshoogte tegen de stammen aangeplakt, maar - vooral bij sterke vermeerdering van het insekt - soms ook veel hooger, tot op een hoogte van 4 à 6 Meter. Bij sterke vermeerdering zitten zij somwijlen ook wel aan de takken der boomen, maar ook soms aan lagere struiken en aan de gewassen, die den bodem bedekken en zelfs op het strooisel.

Ongeveer drie weken nadat de eieren gelegd zijn, komen de rupsjes uit, die aanvankelijk nog geene haarbundels hebben, evenmin als een haarkwast aan 't achtereinde des lichaams (zie bl. 117). De pas uitgekomen rupsjes blijven een korten tijd bijeen zitten, en eten eerst de eischaal op; dan trekken zij gemeenschappelijk langs die stammen op naar de kroon ${ }^{1}$ ), waar de geheele familie, die uit een eihoop is te voorschijn gekomen, althans in den beginne, op een 10 of 12 tal bladeren van de zelfde twijg bijeen zitten. Zij bevreten tot aan hunne eerste vervelling toe de bladerent aan den onderkant, waarbij zij alleen de benedenste opperhuid met een gedeelte van het bladmoes wegnemen, aldus de bladeren skeleteerende. Wanneer zij worden verontrust, dan laten zij zich sneI aan een draad naar beneden zakken. Wanneer men een takje, waarop eene menigte jonge rupsjes zich bevindt, afbreekt, dan blijven er nauwlijks enkelen op zitten. Na de eerste vervelling, waarbij zij de haarbundels op den rug en den staartkwast krijgen, beginnen de rupsen gaten in de bladeren te vreten, en worden ook de fijne bladnerven mee opgegeten. $\mathrm{Na}$ de tweede vervelling vangen zij de voor volwassen beukenborstelrupsen karakteristieke vreterij aan; zij vreten van af den bladrand meer of min boogvormig stukken uit, terwijl zij op heel onregelmatige wijze verschillende lappen laten zitten, die aan den bladsteel

1) B. Altum, „Forstzoölogie”, Ill, 2te Abt. bl. 92. 
blijven hangen, en beginnen intusschen aan een nieuw blad te vreten. Soms ook laten zij heele stukken blad op den grond vallen. In elk geval is een blad, dat zij aantasten, verloren, al eten zij het ook niet geheel op. Eerst wanneer zij de boomen bijkans geheel kaal hebben gevreten, beginnen zij met de bladeren wat zuiniger om te gaan. Over 't geheel gelijkt de vreterij van den roodstaart veel op die van de nonrups, als deze bladeren van loofboomen eet.

Wanneer de rupsen worden verontrust, rollen zij zich dadelijk ineen en laten zich op den grond vallen, waar zij langen tijd onbeweeglijk blijven liggen. Zelfs de luchtbeweging, die door een geweerschot wordt veroorzaakt, doet ze uit de boomen tuimelen, die zich in de omgeving van den schutter bevinden. -

De verpopping geschiedt, al naar de weersgesteldheid, vroeger of later in den herfst, gewoonlijk in 't midden of in de laatste helft van October, soms reeds in September. De pop en hare cocon zijn beschreven op bl. 118. Men vindt de ingesponnen pop meestal op of nabij den grond aan afgevallen bladeren, aan hei- of boschbesstruiken en aan lage heesters, soms ook - maar bij uitzondering - aan takken. -

De beukenborstelrups is niet kieskeurig op haar voedsel; toch kan zij, - ten minste op het continent van Europa, - met recht een "beukeninsekt" worden genoemd, daar zij althans bij voorkeur op beuken leeft. Zoo zag men in het Elspeter bosch op plaatsen, waar de beuken zoo geheel kaal waren gevreten, dat er geen blad meer aan zat, enkele daar tusschen staande eiken soms nog in 't volle bezit van hunne bladeren, of althans nog niet geheel ontbladerd. En terwijl de rupsen daar op vele plaatsen, wegens gebrek aan voedsel, in de beuken hare verkwistende wijze van vreten hadden opgegeven, en nu de bladeren geheel gingen opvreten, zelfs de hoofdnerf inkluis, zag men in de eiken nog voortduren de eigenaardige vreterij, waarbij de rupsen heele stukken blad lieten zitten. 
Wanneer de beuken kaai zijn, tasten zij ongeveer alle andere soorten van loofhout aan: berken, eiken, haagbeuken, hazelaars, alle soorten van populicren, wilgen, iepen, eschdoorns, linden, elzen, esschen, appel- en pereboomen, walnoten, slee- en meidoorn, vuilboom en wegedoorn, vlier; ook hop, rozen, heide, boschbessen, braambessen en frambozen, Daphne, Circaea, zelfs wolfsmelk-soorten. Naaldhout laten zij bijkans altija ongemoeid; toch vindt men soms de rupsen op larix, fijne spar en jeneverbes; het schijnt dat de grove den altijd wordt versmaad. Ook esschen en elzen schijnen zij althans niet gaarne aan te tasten.

Zoolang de roodstaart over oude beukenboomen kan beschikken, waaraan nog bladeren zitten, laat hij de jonge boomen onaangetast; maar wanneer de oude boomen kaal zijn, dan verschoont hij de jongere boomen niet, zelfs niet de éénjarige beukenplantjes. -

Van de massa's rupsen, die men bij buitengewoon sterke vermeerdering in de beukenbosschen aantreft, kan men zich bijkans geen denkbecld maken. De kronen, de takken, de stammen, de lage struiken, heide en boschbessen, de bodem, alles zit vol rupsen; en telkens weer vallen er uit de kronen der boomen op $U$ neer, zoodat men na cene wandeling door een geteisterd bosch er verscheiden aan zijne kleeren met zich mee draagt. Is alles in een bosch kaalgevreten, dan moeten de rupsen eenvoudig verhongeren; allen gaan dan uit de boomen, om te zien of er op den grond nog wat te eten valt, of om daar - zij het ook vóór zij de volledige grootte hebben bereikt te verpoppen. Zoo is de bodem soms hier en daar met eene laag rupsen van een hand breed dikte bedekt. De meeste rupsen komen dan van honger om; diegenen, welke het tot verpopping brengen, leveren in het volgende jaar zeer kleine vlinders. (Van daar de groote variatic in afmeting van het volwassen insekt; zie bl. 116).

De rupsen van Dasychira pudibunda zijn zeer gevoelig voor 
koud, nat, weer; en daar het maar al te dikwijls gedurende den laatsten tijd van haar bestaan als rups een tijd lang achtereen zoodanig weer is, gaat in de meeste jaren een groot aantal der voorhanden rupsen dood. Ook kunnen er enkele jaren velen sterven ten gevolge van vroeg invallende nachtvorsten. Door een en ander laat zich verklaren dat, niettegenstaande het groote aantal eieren, 't welk de vrouwelijke vlinders leggen (3 à 400 stuks), toch eene zóó sterke vermeerdering, dat men van eene "plaag" kan spreken, tot de zeldzaamheden behoort. Want eene vermeerdering op zóó groote schaal kan alleen dàn in eene streek intreden, wanneer het daar niet alleen niet aan het geschikte voedsel (beuken) ontbreekt, maar wanneer daar ook enkele jaren achtereen de weersgesteldheid in de tweede helft van den zomer zóó was, dat de pudibunda-rupsen in leven konden blijven. Het gevoeligst voor nat weer en voor koude zijn de rupsen tijdens hare vervelling en in 't laatst van haar leven als rups, wanneer de tijd der verpopping begint te naderen.

Is het weer een tijd lang achtereen vochtig maar tevens warm, dan gaan er velen dood tengevolge van de verbreiding van infectieziekten, veroorzaakt òf door parasitaire zwammen of door bacteriën. Zoo bleken er op 6 Oct. j.l. in het Elspeter bosch sommige exemplaren door "flacherie" of "slapzucht" te zijn aangetast: eene ziekte, veroorzaakt door eene soort van bacterie, waaraan de rupsen onverbiddelijk sterven, terwijl al de organen binnen de huid worden gedésorganiseerd en in eene bruine, onaangenaam riekende vloeistof worden omgezet, die de slap geworden huid vult.

De roodstaart heeft nog verscheiden andere vijanden. Zoo worden de poppen op groote schaal aangetast door eene zwam, die - al naar den vorm, waarin zij fructificeert - bekend is onder den naam Isaria densa of dien van Cordiceps militaris.

Verder zijn uit de rupsen of wel uit de poppen van den beukenspinner de volgende sluipwespsoorten opgekweekt: 
Pimpla instigator, P.pudibundae, Ichneumon Hartigi, Ichneumon multicinctus, Anomalon excavatum, Ceraphron albipes; in de eieren ontwikkelt zich de larve van eene kleine sluipwespsoort, Teleas Zetterstedti.

Al de genoemde parasieten, zoowel de sluipwespen als de parasitaire draadzwammen en bacteriën, kunnen eerst tot sterke vermeerdering komen, wanneer het insekt, waarin zij leven, reeds in énorm aantal aanwezig is; zij kunnen er dus niet toe meewerken om de vermeerdering van den roodstaart te voorkomen, maar wel om aan eene abnormaal sterke vermeerdering, en dus aan de plaag een einde te maken ${ }^{1}$ ). Bij het voorkomen van eene insektenplaag spelen die van roof levende dieren, welke zich met den beukenspinner in een zijner ontwikkelingstoestanden voeden, een veel belangrijker rol. $\mathrm{N} u$ worden de eieren van dit insekt in niet geringe hoeveelheden gedurende den winter van de boomstammen, eventueel ook van de takken en van de lage struiken, afgezocht door boomkruipers, boomklevers en meezen. De rupsen worden niet veel door andere dieren gegeten: de koekoek, de Vlaamsche gaai, de meezen mogen er al eens eenigen eten, veel maakt dat niet uit. Maar de poppen worden meestal gedurende den winter op vrij groote schaal opgegeten door verschillende soorten van kraaien en eksters, vooral echter door Vlaamsche gaaien en door verschillende soorten van meezen; verder door kortschildkevers en loopkevers. Of ook de wilde varkens, die zich in 't algemeen verdienstelijk maken door het eten van vele schadelijke bosch-

1) Over de verschillende rol, die de van roof levende dieren en de parasitaire organismen tegenover de schadelijke insekten spelen, zie o.a. Ritzema Bos, „Insektenschade op bouw- en weiland" (1883) bl. 75; Ritzema Bos, „Tierische Schädlige und Nützlinge" (1892), bl. 13; Ritzema Bos, „Agriculture zoology (uit het Duitsch vertaald door AINSWORTH DAvis), 2e druk (1900), bl. 273. 


\section{5}

insekten, gedurende den tijd dat deze nabij den grond, onder 't strooisel, enz. vertoeven, ook meewerken om den ,roodstaart" te helpen opruimen, kan ik niet zeggen, en ik kan daarover nergens opgaven vinden.

De schade, door de dasychira-rupsen teweeggebracht, is dikwijls niet zoo groot als het énorme aantal rupsen zou doen verwachten. De vreterij wordt $\mathrm{nl}$. eerst van beteekenis in de tweede hellt van Juli en In Augustus, dus op een tijd, wanneer de bladeren reeds een heelen tijd lang gefunctioneerd hebben, zoodat de aanwas van het bestand (dikke- en lengtegroei) er gewoonlijk niet al te zeer onder lijdt. Zelfs komen de beukenootjes gewoonlijk nog wel tot ontwikkeling, hoewel zij wat kleiner blijven dan in andere jaren. De vreterij grijpt in 't algemeen te laat plaats, dan dat $n o g$ in 't zelfde jaar de knoppen der kaalgevreten boomen weer zouden uitloopen, zooals dat bijv. na kaalvraat van hout door meikevers of door de rupsen van plakker, bastaardsatijnvlinder, donsvlinder, of door ringelrupsen geschiedt. Slechts wanneer het bosch reeds betrekkelijk vroeg kaal was gevreten, reeds in 't laatst van Augustus, dan loopen hier en daar nog enkele knoppen uit. Daarentegen komen de knoppen in de lente van het jaar, volgende op dat, waarin de beuken werden kaal gevreten, doorgaans een acht dagen eerder tot ontwikkeling dan bij boomen, die niet kaal werden gevreten; ook blijft de bebladering geringer, de bladeren zelve blijven kleiner en zijn meer leerachtig; en de gevolgen van de vreterij zijn, ook als deze zich niet herhaalt, nog dááraan te zien, dat zich in het jaar na de plaag slechts weinig beukenoten vormen en dat deze klein blijven en vaak loos zijn. ')

Wanncer eene sterke vreterij twee of drie jaren achtereen in hetzelfde bestand voorkomt, dan kunnen de beuken ernstig onder de vreterij lijden. Niet alleen dat de groei der boomen

') Zie RatZebuRG, „Waldverderbniss”, II (1868), bl. 193. 


\section{6}

dan veel minder wordt dan, gewoonlijk, wat aan de dikte der jaarringen duidelijk zichtbaar is, en dat de scheuten zeer kort blijven; maar soms ook sterven de jonge scheuten op groote schaal af, zelfs kunnen na herhaalde kaalvreterij geheele toppen dood gaan. Ja het kan gebeuren, dat jonge boompjes of ook andere boomen, die in ongunstige condities. verkecren, na twee of drie malen te zijn kaalgevreten, afsterven; maar dat is eene uitzondering.

Het spreekt van zelf dat de totale vernieling van het loof nadeelig op de natuurlijke bodembedekking inwerkt; terwijl daarentegen de bemesting door de uitwerpselen der rupsen, die hier en daar als eene vrij dikke laag den grond bedekken, een sterken grasgroei ten gevolge heeft, die twee à drie jaren duurt. Dit is echter hoogst nadeelig, wanneer men met éćnof tweejarige boompjes te doen hecft, die dan tusschen het hoog opgroeiend gras verstikken. -

De haren, waarmee de borstelrupsen bekleed zijn, Jaten gemakkelijk los, en worden in tijden, waarin eene rupsenplaag heerscht, door den wind overal heen gevoerd. Personen met eene gevoelige huid krijgen daarvan jeukte en uitslag, ofschoon nict zoo erg als van de haren van de eikenprocessierups. Haren, die in de oogen waaien, kunnen aanleiding geven tot oogontsteking.

JUDEICH en NiTSCHE maken ook melding van den schadelyken invloed, dien de bij eene rupsenplaag overal rondwaaiende en op den bodem en op het gras liggende haren op het vee hebben, dat in de buurt graast, en ook op het wild, 't welk daarom de bosschen, waar eene rupsenplaag heerscht, cn ook de aangrenzende bosschen vermijdt ${ }^{1}$ ). TASCHEnBERG ${ }^{2}$ ) schrijft: „Nach jedem Raupenjahre hat das Rotwild an Lunge und Leber zu leiden, und vieles geht ein, ganz entschieden in Folge der vielen Raupenhaare, die mit der Nahrung verschluckt werden."

1) JUDElCH und Nitsche, t. a. p. II, bl. 791.

2) E. L. TASCHENBERG „Forstwirtschaftliche Insektenkunde”, bl. 347. 
Thans wil ik hier nog de bestrijding van den beukenspinner behandelen. Meerdere schrijvers zijn van oordeel, dat elke bestrijding van dit insekt af te raden is, daar zij te kostbaar wordt in verhouding tot de schade, die er door wordt tegengegaan. Zoo NöRDLINGFR ${ }^{3}$ ), die over de bestrijding alleen zegt: „Vertilgung umständlich und ausser Verhältniss zum angerichteten Schadien kostspielig", en NüsSLIN ${ }^{4}$ ), die schrijft: "Begegnung sehr schwierig, da die Vertilgungskosten nicht dem Schädigüngsgrade entsprechen würden". Andere schrijvers daarentegen geven verschillende bestrijdingsmiddelen aan, en vermelden van sommige daarvan gunstige resultaten. - Vóór ik tot de bespreking der middelen overga, die men met meer of minder succès tegen den beukenspinner heeft aangewend, wensch ik echter eenige algemeene opmerkingen te maken. Naar,mijne meening gaat het niet aan, zonder meer, in 't algemeen te zeggen, of het gewenscht is, al of niet cene pudibunda-plaag te bestrijden. Het eene geval is het anderen niet. Wanneer in een zeer groot, vrij wel geïsoleerd liggend beukenbosch eene vreterij eerst wordt ontdekt, wanneer zij zich reeds op zóó groote schaal vertoont, dat men moet aannemen, dat deze vreterij zich reeds in het tweede of zelfs reeds in het derde jaar voordoet, dan is er alle kans dat het aantal parasieten reeds zoodanig is toegenomen, dat aan de vermeerdering van zelf een einde komt. In ieder geval is het dan zeker niet raadzaam, er iets tegen te doen. Het is toch een bekend feit, dat eene pudibundaplaag nooit langer dan drie jaren achtereen in hetzelfde bosch woedt. Trouwens wanneer een bosch van zeer groote uitgestrektheid wordt kaalgevrcten, dan wordt elke bestrijding zóó kostbaar, dat men er wel van af moet zien; te meer omdat de te verwachten schade toch in 't algemeen niet zoo buitensporig groot is.

3) NördliNger, „Lehrbuch des Forstschutzes”, (1884), bl. 230.

${ }^{\dagger}$ NiissLiN ,Leitfaden der Forstinsektenkunde, 2e druk (1913), bl. 375 
Een belangrijke factor, waarvan afhangt, of het al dan nuet raadzaam is, de rupsenplaag te bestrijden, is de vraag: of in de naaste buurt de daarvoor noodige personen te krijgen zijn, en zoo ja, tegen welk loon; uitteraard wordt voor eene degelijke bestrijding veel personeel vereischt, en eene onvoldoende bestrijding geeft al zeer weinig. Krachtig ingrijpen is bepaald gewenscht, wanneer de plaag zich nog maar over een beperkt gebied uitstrekt, en in de naaste omgeving andere beukenbosschen gelegen zijn, waarover zij zich, als er geen bestrijdingsmiddelen werden aangewend, een volgend jaar zou kunnen verbreiden. Eveneens wanneer zich in de naaste buurt van het geteisterde bosch ooftboomgaarden of boomkweekerijen bevinden, waarop de insekten een volgend jaar zouden kunnen overgaan, en waar de alsdan aangerichte schade uit den aard der zaak veel grooter zou worden dan in het beukenbosch zelf.

Overgaande tot de bespreking van de bestrijdingsmiddelen die door verschillende auteurs zijn aanbevolen, vermeld ik $1^{\circ}$. het vernielen der eihoopen. Altum ') maakt melding van de wijze, waarop de Oberförster GöTZE in Glütz dit liet bewerkstelligen. Nadat de Eberswalder geleerde gemeld heeft, dat Götze het verzamelen van poppen, als zijnde onpraktisch, in den herfst 1868 had opgegeven, gaat hij aldus voort: „Dagegen liess er im künftigen Sommer durch Strafarbeiter die Eier, etwa 2 bis 10 Eierhaufen an jedem Stamm, dadurch vernichten, dass dieselben mit dem Hackenstiel, den die Arbeiter horizontal mit den Händen hielten, zerdrückt wurden. Allein die Härte der Eier erforderte, zumal bei ihrer geringen Grösse, einen so starken Druck, dass, da bei der Rundung der Stämme stets nur ein Teil der Eierhaufen unter die zermalmende Walze geraten konnte, der nicht berührte, bez. zerquetschte Teil sich von der Rinde loslöste und unversehrt zu Boden fiel. Er kam daher auf ein anderes Vertilgungsmittel,

1) Altum, t. a, p., bl. 96 . 
nämlich das Bestreichen derselben mit Oel. Dieses bewährte sich in ganz auffallender Weise. Ihre vorhin grau grünliche Farbe veränderte sich sofort in hellbraun, die Schale wurde durchscheinend und fiel später becherförnig ein. Kein einziges Räupchen kam aus geölten Eiern zur Entwickelung. Obschon ich (AlTUM) seit der freundlichen Mitteilung dieser nicht unwichtigen Tatsache durch Hernn GöTzE, keine Gelegenkeit gehabt habe, selbst dieses Vertilgungsmittel zu erproben, so halte ich mich doch von dem Erfolge desselben hinreichend überzeugt. Die Eier werden freilich je nach dem Ausschlüpfen der Falter allmählich abgelegt und sind nur kurze Zeit vorhanden. Allein gerade zu dieser Jahreszeit sind die Tage ausserordentlich lang, sodass an den einzelnen viel geschaift werden kann; die Arbeit selbst ist spielend leicht, sodass Frauen und Kinder senr leicht verwendbar sind, und Arbeitermangel ist dann weniger $\mathrm{zu}$ befürchten als etwa im Frühlinge oder Herbst. Mit Pinseln mit langen Stielen würden sich auch die höher angekitteten Eierhaufen erreichen lassen. Bei einiger Uebung entdeckt ein scharfes Auge dieselben leicht. Dass vor dem Beginne der Arbeit alle Vorkehrungen zur ungehemmten, raschen Ausführung derselben im Grossen getroffen, dass die am schwersten bedrohten Orte festgestellt, überhaupt alle nötigen Dispositionen getroffen sein müssen, versteht sich von selbst. Es ist wichtig, ein spätes Beginnen mit rechtzeitigem Beenden der Arbeit zu vereinigen. Sollten bereits Räupchen im Spiegeln ') sitzen, so werden diese ohne Zweifel ebenfalls durch einen, des leichten Herabfallens derselben wegen von unten nach oben zu führenden

1) "Spiegels" noemt men de tegen een stam dicht bijeen zittende kleine rupsjes, die uit een daar aanwezigen eihoop zijn te voorschijn gekomen. Alvorens tegen den stam op te kruipen en aan de bladeren te gaan vreten, blijven deze rupsjes daar een tijd lang bij elkaar zitten, terwijl zij zich voeden met de eischaal, waaruit zij gekropen zijn. De spiegels" van de non (Liparis monacha) zijn het meest bekend. 
Oelanstrich vernichtet. Dass es auch hier wesentlich ist, die Entstehungspunkte der Calamität, die Brutheerde, zu konstatieren, um gegen diese zeitig mit Energie zur Erstickung jener Keime vorgehen zu können, braucht wohl nicht besonders hervorgehoben zu werden".

De meeste andere schrijvers over schadelijke boschinsekten moeten van het stukdrukken of van het oliën der eihoopjes niets hebben. Ratzeburg ${ }^{1}$ ) noch Richard Hess $^{2}$ ) maken er dan ook melding van; terwijl zij toch wel andere bestrijdingsmiddelen aanbevelen; en NüssLiN ${ }^{3}$ ), die in 't algemeen geene bestrijding van den roodstaart noodig acht, zegt toch nog speciaal van het oliën der eieren, dat het geene afdoende werking heeft. Ook mij wil het voorkomen, dat eene bestrijding 't zij door het wegzoeken, 't zij door het stukdrukken of wel door het oliën van de eihoopjes, in 't algemeen geen aanbeveling verdient. Vooreerst toch is de tijd, dat de eihoopjes of ook de rupsenspiegels tegen de stammen zitten, slechts kort. Gemiddeld zitten de eieren drie weken lang aan de stammen vóór zij uitkomen; maar daar niet alle vlinders te gelijk uit de pop komen en dus ook niet te gelijk hunne eieren leggen, kan het licht voorkomen, dat men met het werk begint, wanneer nog op verre na niet alle eieren gedéponeerd zijn, zoodat men voor eene tweede maal zou moeten rondgaan om die eihoopen met olie te bestrijken, welke bij den eersten rondgang nog niet aanwezig waren. Of als men wachten wilde tot alle eieren gelegd waren, dan zouden allicht uit sommige hoopjes niet alleen reeds de rupsen zijn uitgekomen, maar zouden ook een aantal van de jonge rupsjes reeds naar de kroon zijn gekropen. Verder is het niet alleen hoogst moeilijk, alle eihoopjes aan

') RatzeburG, „Uie Waldverderber”, 6e druk (1869), bl. 162.

2) RICHARD HESs, „der Forstschutz", 2e druk (1887), II, bl. 66.

") Nüs\$liv, „Leitfaden der Forstinsektenkunde”, 2e druk (1913), bl. 376. 
de stammen te vinden; maar bij sterke vermeerdering zitten er ook aan de takken der beuken, aan de lagere struiken en aan de kruidachtige gewassen, die den grond bedekken. Deze zoụden alle aan de vernietiging ontsnappen. Tevens mag niet worden vergeten, dat de eieren slechts los aan de stammen gekleefd zitten, en dat er vele afvallen, die op den grond of tusschen de struiken gevallen, toch wel degelijk uitkomen; ook zulke eieren zou men ongemoeid laten. Bij de vernietiging der eieren is er dus alle kans dat men half werk doet; terwijl de kosten van eene zoo goed mogelijke uitvoering der bewerking zeer hoog worden. Naar mijne bescheiden meening kan het bestrijken van de eihoopjes met olie alleen dàn misschien in aanmerking komen, wanneer men met eene zeer gelokaliseerde plaag in een zeer beperkt gedeelte van een bosch te doen heeft; en dan nog alleen wanneer de eieren vrij wel alle tegen de stammen zijn afgezet, en onder voorwaarde dat men over geschikt personeel kan beschikken. -

$2^{0}$. Het dooden van de rupsen. Dit geschiedt het best, wanneer deze in 't najaar bezig zijn, de boomen te verlaten; men veegt ze dan met bezems van de stammen af om ze te dooden, wat des te gemakkelijker gaat, omdat zij dikwijls, vooral bij koud en nat weer, een paar dagen lang in massa's onder aan de stammen blijven zitten, alvorens zich aan de afgevallen bladeren, de boschbessen of de heidestruiken te gaan inspinnen. Het doelmatigst maakt men daarbij gebruik van korte, stijve bezems of van harde borstels, waarmee men de rupsen op de stammen dood drukt.

De volwassen rupsen laten zich bij de minste storing uit den boom vallen. Slaat men met een houten klopper tegen den stam, dan vallen zij bij honderden op den grond. Waar gelegenheid is, onder de boomen een zeil of laken neer te leggen, kan men ze dáár op laten opvangen en verzamelen. Waar dit moeilijk gaat, kan men ze van den bodem laten oprapen, 
wat evenwel niet zoo gemakkelijk te doen is, wanneer de bodem onder de boomen met boschbessen, heidestruiken, gras, enz. bedekt is.

$3^{0}$. Het aanleggen van lijmringen. De bedoeling van het aanleggen van lijmringen om de stammen is natuurlijk deze: dat men het den rupsen onmogelijk wil maken, tegen de stammen op te kruipen, om aldus de kroon te bereiken, waar zij zullen gaan vreten; zij ontmoeten dan op haren weg een op den stam gesmeerden ring van eene klevende stof, dien zij niet kunnen passeeren. Zij moeten er onder blijven, en kunnen zich dan alleen maar voeden met de bladeren van laag houtgewas, van struiken van boschbessen, enz., die natuurlijk geen voedsel genoeg opleveren, zoodat de rupsen van honger moeten sterven. Men zou hier, even als bij de bestrijding van de nonrupsen, bij het aanbrengen van lijmringen kunnen kiezen tusschen het hooglijmen en het laaglijmen. Het hooglijmen komt daarop neer, dat men de lijmringen aanlegt boven die plaatsen van den stam, waar de eieren zijn gelegd: de jonge, uit het ei komende rupsen zouden dan den lijmring niet kumnen passeeren, zich daaronder ophoopen en van honger sterven. Het laaglijmen grijpt plaats op eene hoogte van 1 Meter 30 of 1 Meter 40 boven den grond, op eene hoogte dus, waarop het strijken van lijm op den stam het gemakkelijkst geschiedt. Hierdoor zullen in 't algemeen slechts zeer weinige jonge rupsjes in hun opstijgen naar boven worden gehinderd, omdat verreweg de meeste eieren hooger worden gelegd. Maar de rupsen van den beukenspinner zijn, even als die van den nonvlinder, zeer beweeglijk, en men kan gerust aannemen dat ieder exemplaar minstens éénmaal in zijn leven uit den boom op den grond valt; dan moet zoo'n rups, om voedsel te kunnen krijgen, weer tegen den stam op kruipen, en zij kan dit niet doen, wanneer zich om dezen stam een klevende lijmring bevindt: de rupsen moeten dus verhongeren, wanneer althans 
alle stammen in het bosch van zoo'n lijmring voorzien zijn; of de rupsen kruipen over den grond verder en trachten nabij gelegen bosschen te bereiken, waar geen lijmringen zijn aangebracht, wat door vanggreppels of isoleergreppels zou kunnen worden onmogelijk gemaakt. (Zie bl. 134).

De Oberförster BODEN ${ }^{1}$ ) heeft met lijmringen proeven in 't klein genomen; en speciaal wat het hooglijmen betreft, kreeg hij geen aanmoedigende resultaten. Zelfs wanneer hij de lijmbanden aanlegde op eene hoogte van 5 Meter, dan bleken er toch nog zoovele rupsjes uit de nog hooger gelegde eieren uit te komen, dat deze nog in staat waren, de beuken kaal te vreten, zij het dan ook wat later dan anders het geval zou geweest zijn. - Met het laaglijmen zijn zonder twijfel eenige resultaten te krijgen; toch zal men ook daartoe bij de bestrijding van de beukenborstelrups niet licht overgaan wegens de te hooge kosten, zoowel aan materiaal als aan werkloon. Vooreerst wat het materiaal betreft: men zou hier beslist gebruik moeten maken van eene soort van rupsenlijm, die althans een paar maanden lang kleverig blijft: teer, dat vroeger voor een gelijksoortig doel bij de bestrijding van wintervlinders en nonrupsen werd gebruikt, droogt te spoedig op. En goede rupsenlijm is niet zoo heel goedkoop, zoodat de kosten van de in een bosch van 50 Hektaren benoodigde hoeveelheid nog al zou oploopen. Ook het werkloon zou in een bosch van die grootte heel wat bedragen; zelfs wanneer men de lijm rechtstreeks op de stammen smeerde, en niet op aan den boom te bevestigen papierbanden. In boomgaarden kan men, om eene ernstige plaag, als bijv. die van den wintervlinder, te bestrijden, met

1), „BODEN, „Versuchsweise Anwendung von Leimringen zur Verhütung des Frasses von Orgyia pudibunda”, in „Zeitschrift für Forst- und Jagdwesen", XXI, (1889), bl. 119-222. 
veel voordeel gebruik maken van lijmbanden 1); maar in een bosch gaat dat bezwaarlijker. En waar het betreft de bestrijding van nonrupsen en rupsen van den dennenspinner, die naaldhoutbosschen kaalvreten en deze of te gronde richten of althans zeer aan 't kwijnen brengen, zou men toch nog eerder tot het lijmen der stammen kunnen overgaan, dan waar het betreft de bestrijding van den "roodstaart" in de beukenbosschen, wijl de gevolgen van het kaalvreten hier toch betrekkelijk weinig ernstig zijin. Dat het "hooglijmen" nog veel moeilijker gaat en veel meer werkloon kost dan het "laaglijmen", spreekt wel van zelf. Omdat men er naar mijne meening wel nooit toe zal overgaan, den beukenspinner met lijmbanden te bestrijden, zal ik er hier niet verder over uitweiden.

$4^{0}$. Het aanleggen van vang- of isoleergreppels kan dienen om te verhinderen dat de rupsen, als zij een bepaald bosch of gedeelte van een bosch hebben kaalgevreten, de kaalgevreten boomen verlatende, over den grond naar een aangrenzend perceel trekken, dat nog niet is aangetast. Men geeft aan de greppels eene diepte van 30 à 35 c.M. enl eene breedte van 25 à 32 c.M.; men laat ze naar den kant van het aangetaste gedeelte van het bosch schuins afloopen, maar geeft ze aan den kant naar het nog niet aangetaste bosch toe eenen loodrechten wand. In die greppels maakt men, telkens op een afstand van 5 of 6 schreden, vanggaten ter diepte van $10 \frac{1}{2}$ à 15 c.M. Wanneer nu de rupsen in het aangetaste bosch alles hebben kaalgevreten en zich naar den grond begeven om andere boomen te beklimmen, dan geraken zij in de vanggreppels. Te vergeefs beproeven zij, tegen den steilen wand naar boven te kruipen; en door de greppels voortkruipende, komen zij in de vanggaten, waar zij nog minder uit kunnen komen. Toch is het raadzaam, dagelijks de greppels na te zien en de daarin aanwezige rupsen te vernielen. ЈUDEICH

1) Zie hierover o.a. liet Vlugschrift no. 14, uitgegeven door het Instituut voor phytopathologie (Juni 1914), op aanvrage gratis verkrijgbaar. 
en NiTSCHE ') schrijven : „Die Raupe ist... träge und wandert nicht gern, durchkriecht aber Isolierungsgräben sehr leicht, sodass wenn dieselben etwas nützen sollen, die Raupen in ihnen täglich vernichtet werden müssen".

$5^{0}$. Het verzamelen van de poppen in hare winterkwartieren. Deze bestrijdingswijze wordt door RATZEBURG ${ }^{2}$ ) het meest op den voorgrond gesteld. De grondlegger van de kennis der Midden-Europeesche boschinsekten maakt daarbij de opmerking, dat dit wegzoeken alleen behoeft te geschieden aan de randen van de gedeelten van bosschen, welke geheel kaal zijn gevreten, niet in het midden van aldus geteisterde plekken in het beukenwoud, wijl - volgens hem - op de laatstbedoelde plaatsen de poppen zelden in het volgende jaar zich verder zullen ontwikkelen, omdat deze in haren rupstoestand wel bijkans altijd honger zullen hebben geleden. Het komt mij voor dat RaTzEBURG zich hier al te positief uitlaat. Het is toch bekend dat rupsen, die te weinig voedsel ter beschikking hebben, zich niet alleen vaak gaan verpoppen, wanneer haar tijd daarvoor gekomen is, maar dat ook uit zulke poppen meestal vlinders uitkomen; de rupsen, die onvoldoend gevoed zijn, bereiken echter de normale grootte niet, en natuurlijk evenmin de daaruit ontstaande poppen en vlinders. (Zie boven, bl. 122). Ook leveren de onvoldoend gevoede rupsen gewoonlijk mannetjes op ${ }^{3}$ ). En om deze reden èn ook omdat allicht van de rupsen op de plaatsen, waar zij het meest opeengehoopt hebben geleefd, velen geparasiteerd zijn, zou men $\mathrm{m}$. i. bij het verzamelen van de insekten in de winterkwartieren zich toch wel in hoofdzaken

1) JUdeich und Nitsche, t.a.p. bl. 792.

) RATZEBURG, „Die Waldverderber", 6e druk (1869), bl. 182.

3) CARL DüsING, „Die Regulierung der Geschlechtsverhältnisse bei der Vermehrung der Menschen, Tiere und Pflanzen" in "Jenaische Zeitschrift für Naturwissenschaft", dln. XVII (1884), bl. 770 enz.

H. LANDOIS, „Ueber das Gesetz der Entwickelung der Geschlechter bei den Insecten", in „Zeitschr. für wissenschaftliche Zoologie”, XVIII (1867.) 


\section{6}

aan den raad van RATZEBURG kunnen houden, zij het dan ook niet om de door dezen aangegeven reden. Waar de bodembedekking uit heidestruiken of boschbessen bestaat, is het wegzoeken der poppen moeilijk uitvoerbaar; waar deze struiken ontbreken, gaat het gemakkelijker. Daar vindt men vaak hoopen afgevallen bladeren, waaraan zich heele groepen aaneengesponnen poppen bijéén bevinden. Het verzamelen van die poppen kan echter juist bezwaarlijk worden, omdat men met de poppen zoo groote massa's blad moet verzamelen, dat de emmers, die men meeneemt, zeer spoedig gevuld zijn. Het bijéénharken van de afgevallen bladeren met de daaraan bevestigde poppen, het verwijderen dus van het strooisel uit de bosschen, is in 't algemeen niet raadzaaam, omdat daaraan veel nadeelen verbonden zijn. Het komt mij voor, dat men in sommige gevallen met succès gebruik zou kunnen maken van eene methode, die ik indertijd bij de bestrijding van de dennenbastaardrups (Lophyrus Pini) heb toegepast, welk insekt even als de beukenborstelrups in het strooisel verpopt '). De methode komt hierop neer: men harke het strooisel en de ruigte, waarmee de bodem bedekt is, hier en daar in hoopen bijéén, en bestrooie deze hoopen met flink wat ongebluschte kalk, die er door heen wordt gewerkt. Daarna wordt water over de hoopen heen gegoten, waardoor de kalk wordt gebluscht; de daarbij ontstaande hitte doodt de poppen. Na eenigen tijd, bijv. na cen 14 dagen, onderzoekt men de poppen, om te zien of zij dood zijn; dit is het geval, wanneer het achterlijf van de uit de cocon genomen pop zich niet meer laat buigen, maar geheel stijf is, of als de lichaammassa, al naar de weersgesteldheid van den laatsten tijd, verschrompeld is of wel week en in rotting overgaan. Men onderzoekt uit iedere hoop strooisel een aantal

1). Zie „Tijdschrift voor Plantenziekten”, deel I (1895), bl. 13, en "Tijdschrift der Nederl. Heidemaatschappij", jaargang VIl (1895) bl. 55: RITZEMA Bos, „Bestrijding van de dennenbastaardrupsen”. 
poppen; blijkt het dat zij allen dood zijn, dan wordt het strooisel weer over den bodem van het bosch verbreid. Op deze wijze doodt men met niet al te veel moeite en kosten de overwinterende insekten, terwijl men het strooisel voor het bosch behoudt. De boschgrond wordt er door de toevoeging van kalk niet slechter op; men zij derhalve niet te zuinig met de kalk, opdat er zich hitte genoeg ontwikkele voor het dooden der poppen.

Bezwaren, die men bij de toepassing der aangegeven methode in sommige bosschen kan ondervinden, zijn: $1^{0}$. de moeilijkheid om water genoeg in het bosch te krijgen; $2^{0}$. het bedekt zijn van den bodem met boschbessen of heidestruiken. Voordeelen van de aangegeven methode zijn: $1^{0}$ men doodt althans het meerendeel der poppen, die in 't strooisel zitten; $2^{0}$. men behoudt het strooisel voor het bosch; $3^{0}$. men verrijkt den bodem door bemesting met de doode insekten en met kalk.

$6^{0}$. Het vangen van de volwassen vlinders, terwijl deze over dag stil zitten tegen de stammen. Dit bestrijdingsmiddel vind $\mathrm{ik}$ nergens aangegeven, ofschoon het $\mathrm{m}$. i. even goed uitvoerbaar zal blijken te zijn als het vangen van de nonrupsvlinders, zooals dat in 1908 in de dennenbosschen bij Tilburg en Alphen (N.-B.) geschiedde 1 ). Het vangen gebeurde daar zoowel door kinderen als door volwassen personen; de gevangen vlinders werden per kilogram betaald. Daar het doel van het vangen der vlinders ook vooral was: het tegengaan van de uitbreiding der plaag, waarbij het gewenscht was, de randen rondom het zwaar beschadigde centrum zooveel doenlijk vrij van vlinders te honden, - zoo werden aan die randen, waar het zoeken in taak niet loonend was, door vertrouwde arbeiders tegen daggeld vlinders verzameld. -

1). „Rapport betreffende het optreden van den Nonvlinder in Nederderland", uitgegeven door de Directie van den Landbouw te 's-Gravenhage, (1909), bl. 13. 
Het zij mij thans vergund, mee te deelen wat in de Elspeter bosschen ter beteugeling van de plaug is geschied, en wat - naar mij voorkomt - nog verder zou dienen te gebeuren.

Reeds op 6 October waren een dertig personen, meest allen jongens, bezig met rupsen te verzamelen Groote massa's rupsen zaten er tegen de stammen, waar zij gemakkelijk konden worden verzameld; andere werden van de boschbessen afgezocht; soms werden de boomstammen geschud of in trilling gebracht, door met een houten klopper tegen de stammen te slaan, waardoor de rupsen in massa's op den grond neervielen, om daar te worden opgeraapt. Bij gelegenheid van het bezoek, op 6 Oct. j.l. aan het geteisterde bosch gebracht, werden algemeen de reeds door het Bestuur van de Elspeter bosschen genomen maatregelen geprezen; echter werd de wenschelijkheid uitgesproken dat deze nog op grooter schaal zouden worden uitgevoerd. Het genoemde Bestuur was daartoe bereid en er werden nog veel meer personen aan 't werk gezet. Op 28 October berichtte mij de Heer Tutein Noltenius, dat in 't geheel $47^{1} / 2$ Hektoliter rupsen waren verzameld; daar er gemiddeld \pm 850 stuks in een Liter gaan, bedroeg alzoo het geheele aantal aldus verzamelde rupsen opgeveer 4 millioen. Voor een Liter rupsen werd betaald 4 ct., zoodat de kosten van het vangen konden worden gesteld op een kleine $f 200$. Bovendien zijn, toen deze vangst was afgeloopen, nog een paar dagen in daghuur de boomstammen met bezems bewerkt, om de daaraan nog aanwezige rupsen te vernietigen.

Er heeft dus eene duchtige opruiming van rupsen plaats gehad. Toch blijkt deze opruiming nog niet geheel voldoende te zijn geweest. Want in het laatst van November bezocht de Heer J. van RosendaEL, houtvester bij het boschwezen in Ned.-Indië, met verlof in Nederland, en tijdelijk werkzaam als adsistent van den Heer A. J. van SchermBeEK, leeraar aan de Rijks Hoogere Land-, Tuin- en Boschbouwschool, bij gelegen- 
heid van eene excursie het geteisterde bosch, en verzamelde onder het strooisel nog eene vrij aanzienlijke hoeveelheid ingesponnen poppen. Het zal dus raadzaam zijn, dat gedurende den winter aan deze poppen nog de noodige aandacht worde gewijd. Op die plaatsen, waar zich nog een aanmerkelijk aantal poppen in het strooisel bevinden, late men dit bijeenharken; men late de hoopen strooisel vermengen met eene flinke hoeveelheid ongebluschte kalk, die door overgieting van de hoopen met water wordt gebluscht; men overtuige zich een 14 dagen later er van of de poppen dood zijn, en verbreide daarna het strooisel weer over de kaalgeharkte plekken. (zie bl. 136).

In het volgende jaar (Mei en Juni) lette men op het verschijnen dervlinders; zoo noodig late men deze wegvangen.Aan het slot van mijn artikel gekomen, kan ik niet nalaten, te doen uitkomen, dat het Bestuur van het Elspeter bosch een lofwaardig voorbeeld heeft gegeven bij de bestrijding van de pudibunda-plaag in de door dat Bestuur beheerde beukenbosschen.

Moge ook al volkomen terecht in Duitschland in vele gevallen niets worden gedaan ter bestrijding van eene pudibundaplaag, omdat eene degelijke, eenigszins afdoende bestrijding uiterst moeilijk is, en de daarvoor benoodigde kosten te hoog loopen ten opzichte van de schade, die men door eene krachtdadige bestrijding voorkomt ${ }^{1}$ ), - in het onderhavige geval was het m.i. wat anders. Al is het waar dat de beukenspinner over het grootste gedeelte van land verbreid is, overal waar beuken groeien en soms ook nog wel waar die niet te vinden zijn, als er maar ander loofhout groeit, zoodat de mogelijkheid van eene massavermeerdering van dit insekt ook op andere plaatsen in ons land niet ontbreekt, - zoo leert toch de ervaring dat - om welke reden dan ook - Nederland, althans tot dusver, weinig geschikt schijnt voor eene dergelijke vermeerdering.

1.) Zie bl. 127 van dit artikel. 
Maar waar er nu toch eenmaal eene buitengewoon sterke vermeerdering was tot stand gekomen, daar zouden, als men niet had ingegrepen, vrij stellig een volgend jaar groote massa's vlinders zijn ontstaan, die zich natuurlijk in de eerste plaats over andere dicht bij gelegen beukenbosschen, maar - daar de vlinders, ook de wijfjes, bij nacht over vrij groote afstanden voortvliegen - ook over verder afgelegen loofhoutbosschen, plantsoenen, enz., ook over boomgaarden, hadden kunnen verbreiden en daar eieren zouden hebben gelegd. En ook wanneer nu een volgend jaar de omstandigheden voor het insekt minder gunstig mochten zijn dan dit jaar, zou op deze wijze toch allicht over een vrij groot gebied belangrijke schade aangericht zijn. Wijl in het gegeven geval de plaag zich nog niet over een zóó groot gebied uitstrekte, dat eene degelijke bestrijding onmogelijk scheen en eene flinke bestrijding niet overmatig veel geld behoefde te kosten, acht ik het eene zaak van wijs beleid, dat het Bestuur van de Elspeter bosschen de bestrijding dadelijk krachtdadig ter hand heeft genomen; en Z. K. H. Prins Hendrik der Nederlanden, wiens groote belangstelling in alles wat den land- en boschbouw betreft, algemeen bekend is, heeft er veel toe bijgedragen dat de zaak nog krachtiger aangepakt is dan aanvankelijk reeds geschiedde.

Wageningen,

J. RITZEMA BOS.

11 November 1914. 